УДК 94(47).084.5.6

ВАСИЛЬЕВ Юрий Альбертович - доктор исторических наук, профессор Московского гуманитарного университета (111395, Россия, г. Москва, ул. Юности, 5; region@тоsgu.ru)

\title{
ЛЮДИ И СУДЬБЫ КОМИНТЕРНА: ТУУРЕ ЛЕХЕН
}

\begin{abstract}
Аннотация. В публикации освещаются неизвестные страницы деятельности Коминтерна в 1920-1930-е гг. В фокусе внимания - специалист по военной работе аппарата Исполкома Коминтерна (ИККИ) Тууре Лехен (Альфред). В контексте персональной истории раскрывается содержание работы Коминтерна в Германии, Австрии, освещается деятельность по обеспечению работы секретных комиссий, созданных в Орготделе ИККИ. Автор рассматривает сюжеты, связанные с механизмом функционирования Коминтерна, представляет характеристики ряда сотрудников Коминтерна, с которыми приходилось взаимодействовать Альфреду.
\end{abstract}

Ключевые слова: Тууре Лехен, Альфред, Исполком Коминтерна (ИККИ), военная работа, нелегальная деятельность

И сследовательская традиция разработки персональной истории в России имеет давние корни [Васильев, Васильева 2014]. Объект персональной истории в данной статье - сотрудник Коминтерна, которого звали Альфред. Настоящие же данные были записаны в паспорте гражданина СССР: Тууре Иванович Лехен. С учетом его финляндского происхождения можно сделать уточнение: Тууре Вальдемар Лехен (Lehen). Отца Ивана на родине - в Финляндии - звали Иоганн Герман. Тууре Лехен пользовался многими псевдонимами. После окончания Военной академии в Москве, когда он выполнял «особые поручения» при наркоме по военным и морским делам в Реввоенсовете СССР в 1924-1926 гг, он получил агентурный псевдоним «Альфред». В анкетных данных, помимо военной специальности, неизменно указывалась еще одна специальность - журналист. В 1923-1926 гг. Альфред много раз направлялся в командировки в Германию и Австрию для выполнения специальных заданий в области нелегальной деятельности. В период работы в Исполкоме Коминтерна (1927-1936 гг.) появились новые псевдонимы: Август Вейнбергс, Эмиль Бьерклунд, Эрнст Гессель, Карл Эванг, Альфред Маркус.

В период командировки в Германию в 1926 г. Лехен познакомился с Гансом Киппенбергером. Еще до его приезда Киппенбергер был выдвинут на руководящую работу в военном аппарате компартии Германии. Однако вскоре после начала работы в Германии Лехен поставил вопрос о снятии Киппенбергера с работы за его «большую склонность к интригам». Но ЦК КПГ оставил его на работе, поскольку никто не отрицал наличия у Киппенбергера незаурядных способностей информатора и разведчика. Руководители компартии не раз выражали свое удовлетворение результатами его работы, он пользовался особым доверием Эрнста Тельмана. В 1926 г. Лехен смог детально ознакомиться с работой военного отдела ЦК КПГ, т.к. находился в Германии почти весь год. Однако, по его свидетельству, он мало имел отношения к основной работе Киппенбергера - разведке. По этим делам Киппенбергер был связан с резидентом разведуправления штаба РККА, роль Лехена в этом вопросе сводилась только к «общему наблюдению». Ему было известно, что Киппенбергер был связан с многими источниками информации, в качестве которых служили представители буржуазного и дворянского происхождения. Основная же задача Лехена, с которой он приехал в Германию по поручению ИККИ, заключалась в ликвидации тайной военной организации КПГ и в связи с этим - в 
разъяснении вопросов вооруженного восстания (против путчизма ультралевых) в печати, на курсах партработников ${ }^{1}$.

В 1927-1936 гг. Лехен работал в аппарате Исполкома Коминтерна (ИККИ) в качестве инструктора Орготдела, затем - референта отдела кадров. Он хорошо владел русским и немецким языками, знал также испанский и французский. Имел репутацию квалифицированного военного специалиста. В анкетных данных свою военную специальность именовал «штабной работник». У Орготдела была не только открытая деятельность, но и закрытая - конспиративная. В нее входила, в частности, нелегальная военная деятельность компартий. Именно эта сфера деятельности стала функциональной обязанностью Тууре Лехена. Руководители Коминтерна видели в нем специалиста, который сможет устранить прежние ошибки Коминтерна в тактике единого фронта.

Строго засекреченными подразделениями ИККИ являлись две комиссии, созданные при Орготделе, которые занимались вопросами нелегальной деятельности: Постоянная военная (антивоенная или военно-конспиративная) комиссия и Постоянная комиссия по нелегальной работе. Военная комиссия имела кодовое обозначение «Комиссия М» (Militar-Antimilitarkommission). После реорганизации Орготдела в 1926 г. «Комиссия М» занималась разработкой вопросов тактики антимилитаристской деятельности компартий в армии и на флоте капиталистических стран, пропагандой методов революционной вооруженной борьбы, созданием массовых организаций рабочей самообороны (Союз красных фронтовиков и т.п.), борьбой против провокаций. «Комиссия М» обсуждала отчеты компартий по антивоенной работе. В обязанности Нелегальной комиссии входила защита кадров компартий от полицейских репрессий, провалов, от проникновения в партийные структуры полицейских провокаторов.

Пришедший на работу в Орготдел в январе 1927 г. военный специалист Тууре Лехен занимался обеспечением деятельности указанных комиссий. В 1928-1936 гг. Тууре Лехен являлся членом Военной комиссии ИККИ. В ее состав, кроме руководителя Орготдела ИККИ Б.А. Васильева и Т.И. Лехена, входили также Я.К. Берзин (начальник разведуправления штаба РККА), Б.Б. Бронковский (Бортновский) и С.В. Жбиковский, имевшие большой практический опыт работы в разведуправлении. По свидетельству Лехена, ему «приходилось часто критиковать Берзина за его ведомственный эгоизм в вопросах военной работы компартий. [О.А.] Пятницкий меня раз в очень резкой форме “осадил” за такую критику. Жбиковский вообще вел себя как провокатор, постоянно настаивая на самых резких формах военной работы. Я наотрез отказался с ним работать. Почти во всех спорных вопросах Жбиковского поддерживал Бронковский, что для меня было загадкой, т.к. Бронковского считали толковым человеком» 2 .

VI конгресс Коминтерна (1928 г.) принял специальную закрытую резолюцию об антивоенной работе компартий. Военные комиссии в отдельных компартиях и нелегальные боевые организации, существовавшие в нескольких компартиях (в Германии, Италии, Болгарии, Польше, Финляндии) были распущены или переориентированы на организацию службы пролетарской самообороны, охраны массовых мероприятий компартий. В Орготделе была подготовлена инструкция по военной работе секций ИККИ. В ней констатировалось, что нередко нелегальные боевые организации (так называемая военка) пытались действовать вне контроля руководства компартий. Поэтому считалось недопу-

1 Российский государственный архив социально-политической истории (РГАСПИ). Ф. 495. Оп. 269. Д. 8. Л. 82.

2 РГАСПИ. Ф. 495. ОП. 269. Д. 8. Л. 84. 
стимым создание самостоятельного военного аппарата наряду с партийными организациями.

В ноябре 1929 г. работу «Комиссии М» продолжила созданная решением Политкомиссии ИККИ в структуре Орготдела Комиссия по специальным вопросам - она часто фигурировала в документах под старым названием. Ее возглавил Б.Б. Бронковский, однако основную работу координировал Т. Лехен [Шириня 2006: 442]. Специальная комиссия посылала своих инструкторов в командировки за рубеж для оказания помощи компартиям в организации антивоенной работы, в установлении контактов с солдатами и призывниками, в активизации антивоенной пропаганды. Наряду с задачей создания нелегальных ячеек в воинских частях, главное внимание уделялось организации работы в системе довоенной подготовки: в бойскаутских и других подобных организациях, в спортивных клубах, матросских тавернах и пр.

«Комиссия М» Коминтерна руководила подготовкой военных кадров для ряда компартий. В ИККИ были секретные режимные подразделения - военные школы Коминтерна, с 1927 по 1931 г. их работой руководил Тууре Лехен. 25 октября 1929 г. Политбюро ЦК ВКП(б) разрешило ИККИ внести изменения в учебную программу МЛШ: «расширить путем введения новых военных дисциплин» [Адибеков, Шахназарова, Шириня 1997: 171].

В функцию Комиссии по специальным вопросам перешла от прежней Нелегальной комиссии защита кадров компартий. Коминтерн ограничивал увлечение руководителей в некоторых компартиях физическими расправами, террористическими актами со стороны спецгрупп по борьбе против провокаторов и предателей. ИККИ вмешивался в подобную политику компартий. Приоритетной утверждалась установка: главным методом борьбы против провалов и полицейских провокаторов является улучшение всей системы конспиративной работы и умелое сочетание нелегальной деятельности с легальной.

В качестве представителя ИККИ в 1928-1932 гг. Лехен ездил в Германию несколько раз на 1-2 месяца с конкретными поручениями, в большинстве случаев для подбора курсантов для специальных военных школ Коминтерна в СССР. Он постоянно имел дело с Гансом Киппенбергером, т.к. военный отдел ЦК КПГ принимал активное участие в проверке курсантов. В докладной записке в ИККИ он сообщал: «Но еще меньше, чем раньше, я мог контролировать работу разведывательного аппарата, который был частью военного отдела ЦК под общим руководством Киппенбергера, он контролировался и финансировался заинтересованным органом. Такое переплетение партийного и непартийного аппаратов меня все время беспокоило, и я неоднократно ставил вопрос о полной передаче разведывательного аппарата заинтересованным органам и его отделении от партийного аппарата. Когда Киппенбергер приехал в Москву (я его не видел с 1932 г.), я с ним резко разошелся по вопросу о нелегальной партийной организации в Германии, т.к. его “планы” реорганизации партии означали бы на деле полное подчинение всей партийной организации его военному аппарату, мне стало ясно, что эти планы имели фракционную тенденцию» .

Работа Орготдела Коминтерна носила засекреченный характер, поскольку она тесно соприкасалась с деятельностью советских разведок, руководимых в то время Я.К. Берзиным (разведуправление штаба РККА -военная разведка) и М.А. Трилиссером (иностранный отдел - ИНО - внешняя разведка ведомства ОГПУ). Осуществлялся регулярный сбор информации от «М» - групп компартий, входивших в Коминтерн, сведений о военных приготовлениях капита-

${ }^{1}$ РГАСПИ. Ф. 495. ОП. 269. Д. 8. Л. 83. 
листических стран, расположении вооруженных сил Японии, Чехословакии, Франции, Англии, Италии, Румынии, Польши, Финляндии и др.

Существует мнение, что Тууре Лехен являлся военным разведчиком. Так ли это? Несомненно, Лехен занимался специфической деятельностью в области нелегальной разведки в период его пребывания в Наркомате по военным и морским делам СССР в 1924-1926 гг. в качестве сотрудника «по особым поручениям» при наркомвоенморе. Известно, что с 1923 г. в Германии работали нелегальные специалисты из разведуправления штаба РККА. В советском представительстве в Берлине находилась группа инструкторов, так называемая группа Алоиза - Стефана Жбиковского. Его ближайшими помощниками являлись Август Гайлис (псевдоним Нойберг) и Тууре Лехен (Альфред). С апреля 1925 г. руководителем Военного аппарата КПГ стал Ганс Киппенбергер, сотрудник разведуправления, прошедший обучение в СССР. В Германии был создан нелегальный военный аппарат КПГ (М-аппарат).

В период пребывания Лехена в Германии были наработаны источники и связи в полиции и рейхсвере, а также в организациях праворадикального толка. Благодаря этому сотрудники Военного аппарата КПГ своевременно узнавали о мерах против нелегальной деятельности компартии, добывали копии документов и приказов о запланированных полицией акциях. Кроме того, удалось проникнуть в руководство охранной полиции, полицай-президиума, «Стального шлема», «Вервольфа», Германской народной партии, а также бронетанковых войск.

Опыт нелегальной работы за рубежом нашел отражение в обстоятельной информации о ситуации в Австрии. В июле 1926 г. Наркомат по военным и морским делам СССР направил секретарю ИККИ Д.З. Мануильскому «доклад нашего работника в Германии тов. Альфреда. Тов. Альфред по нашему указанию поехал в Австрию для ознакомления на месте с постановкой военно-партийной работы. Настоящий доклад является результатом этой поездки» ${ }^{1}$. Австрийский опыт пригодился Лехену в первый же год его работы в Коминтерне. В августе 1927 г. в Орготделе ИККИ обсуждали уроки антифашистского выступления рабочих в Вене 15 июля 1927 г. Во время многотысячной демонстрации трудящихся полиция открыла огонь, рабочие стали штурмовать полицейские участки и Министерство юстиции. В Вене была объявлена всеобщая забастовка протеста. Однако властям удалось подавить это стихийное восстание. Главный урок массовых выступлений сводился к военно-технической неготовности компартии Австрии к подобным акциям ${ }^{2}$. Руководитель Орготдела ИККИ Б.А. Васильев написал 8 августа письменное поручение, адресованное Лехену: «Надо было бы попытаться составить сводку (или точнее, быть может, - анализ) уроков венского восстания» 3 .

Следует отметить, что официально советская разведка и работа ОГПУ были отделены от коминтерновской работы еще в 1925 г. Политбюро ЦК ВКП(б) в последующие несколько лет приняло ряд решений о недопустимости смешивания внешней разведки с партийной деятельностью. 23 апреля 1928 г. было принято соответствующее решение, требовавшее «строжайшего проведения принципа невмешательства» советских представителей во внутренние дела иностранных государств. Так, 19 февраля 1932 г. Лехен информировал в докладной записке Д.3. Мануильского о некоторых случаях подобных нарушений и подчеркивал «недопустимость совмещения партийной работы и органов

\footnotetext{
1 РГАСПИ. Ф. 495. ОП. 269. Д. 8. Л. 3.

2 Коминтерн против фашизма: документы. М.: Наука. 1999. С. 192.

3 Там же.
} 
ГПУ» ${ }^{1}$. В дальнейшем при переходе на работу в ОГПУ-НКВД или разведуправление штаба РККА иностранные коммунисты, как правило, выводились из состава Коминтерна. Действовало четкое указание: ответственный функционер компартии не должен одновременно являться сотрудником советских разведывательных органов.

Опыт нелегальной работы в Германии дал возможность Лехену высказать собственные суждения о методах работы органов разведки ОГПУ за рубежом. В записке Лехена от 19 ноября 1932 г., адресованной руководству ИККИ, констатировалось: «Немецкие товарищи, занимающиеся в нелегальном аппарате КПГ борьбой против провокации, жалуются на неправильные методы работы органов ГПУ. Имеется ряд случаев, когда эти органы без ведома и согласия руководящих органов партии поручали работу отдельным членам партии, которые совмещали эту работу с их партийной работой» ${ }^{2}$. Примечательно, что в донесениях Лехена руководству отмечались нарушения партийных установок в отношении сотрудничества с органами разведки ОГПУ, однако Разведупр, как правило, не упоминался.

Во время работы в аппарате Коминтерна Тууре Лехен проявил склонность к аналитической деятельности в области военной работы, которой он занимался. 10 ноября 1929 г. он написал записку о пролетарской самообороне, адресованную В. Мицкевичу-Капсукасу. В ней сообщалось: «По вопросу о пролетарской самообороне у нас была создана комиссия под председательством тов[арища] [Ф.] Денгеля. Комиссия собралась раз и пришла к выводу, что работу нужно начать с основательного разбора германского опыта в этом вопросе. Так как за последнее развитие вопроса нет почти никаких данных, то решено было вызвать из Германии кого-нибудь из хорошо осведомленных товарищей со всеми возможными документами. Денгель взялся это дело организовывать. Но ни документов, ни человека пока нет, и нет ответа, несмотря на все запросы. Может быть, Вы можете подтянуть кого-нибудь, чтобы это дело пошло. Без такого исчерпывающего материала трудно поставить вопрос достаточно конкретно. А теперь я предлагаю начать на страницах "Коммунистического Интернационала" дискуссию по вопросам пролетарской самообороны. Везде в этом вопросе имеются большие неясности, даже в Германии, где дело обстоит лучше всего. Это, по-моему, одна из главных причин того, что дело не подвигается вперед. Нигде в коммунистической прессе не видно даже попыток серьезного обсуждения этого вопроса. Поэтому я решил “рискнуть” и написал приложенную статью, которая имеет целью спровоцировать продуктивную дискуссию. Статья написана на основании обмена мнений с товарищами из разных стран. Между прочим, вопрос довольно живо обсуждался на конференции финской компартии» 3 .

В отличие от многих коллег по Коминтерну, судьба уберегла Тууре Лехена от репрессий в аппарате ИККИ (в 1930-е гг.), а также в послевоенные годы в период «Ленинградского дела» [Васильев, Шепелев 2016]. В 1946 г. по решению высшего партийного руководства СССР он был направлен на политическую работу на родину - в Финляндию. В 1967 г. Т.И. Лехен был награжден орденом Красного Знамени, в 1986 г. удостоен звания почетного доктора МГУ им. М.В. Ломоносова.

\footnotetext{
${ }_{1}^{1}$ РГАСПИ. Ф. 495. ОП. 25. Д. 1335. Л. 115.

2 РГАСПИ. Ф. 495. ОП. 25. Д. 1335. Л. 115.

3 РГАСПИ. Ф. 495. ОП. 25. Д. 1342. Л. 64.
} 


\section{Список литературы}

Адибеков Г.М., Шахназарова Э.Н., Шириня К.К. 1997. Организационная структура Коминтерна. 1919-1943. М.: РОССПЭН. 287 с.

Васильев Ю.А., Васильева М.Ю. 2014. Влияние идей Христиана Вольфа на мировоззрение М.В. Ломоносова. - Власть. № 3. С. 121-125.

Васильев Ю.А., Шепелев В.Н. 2016. Борьба политических элит в условиях позднего сталинизма. Карельский отголосок «Ленинградского дела». 19491950 гг. - Исторический архив. № 3. С. 3-31.

Шириня К.К. 2006. Коминтерн в 1933 году. М.: Экслибрис-Пресс. 520 с.

VASILIEV Yuriy Albertovich, Dr.Sci. (Hist.), Professor, Moscow University for the Humanities (5 Yunosti St, Moscow, Russia, 111395; region@mosgu.ru)

\section{PEOPLE AND DESTINIES OF THE COMINTERN: TUURE LEHEN}

Abstract. The publication highlights the unknown pages of the Comintern's activities in the 1920s - 1930s. The focus of attention is Tuure Lehen (Alfred), a specialist in military work of the apparatus of the Executive Committee of the Comintern. The author reveals the content of the work of the Comintern in Germany, Austria, activities to ensure the work of secret commissions created in the Organizational Department of the Executive Committee of the Comintern in the context of the personal history. The paper presents the plots related to the mechanism of functioning of the Comintern, and the characteristics of a number of employees of the Comintern, with whom Alfred had to interact.

Keywords: Tuure Lehen, Alfred, Executive Committee of Comintern, military work, illegal activities 